\title{
Sustainability of sunflower cultivation for biodiesel production in central Italy according to the Renewable Energy Directive methodology
}

\author{
Daniele Duca, Giuseppe Toscano, Ester Foppa Pedretti, Giovanni Riva \\ Dipartimento di Scienze Agrarie, Alimentari e Ambientali, Università Politecnica delle Marche, \\ Ancona, Italy
}

\begin{abstract}
The use of renewable energies as alternative to fossil fuels has value from different points of view and has effects at environmental, social and economic level. These aspects are often connected to each other and together define the overall sustainability of bioenergy. At European level, the Directive 2009/28/EC gives the basic criteria for the estimation of sustainability of biofuels and indicates a minimum threshold of $35 \%$ of greenhouse gas saving for a biofuel in order to be considered sustainable. The Directive gives the possibility to identify standard regional values for the cultivation steps that could be utilized for the certification. This paper aims to give a contribution to the definition of these values considering the RED methodology applied to the sunflower cropped in central Italy which is characterized by a hilly landscape and not-irrigated crops. To determine input and output of sunflower cultivation in the central Italy, the results of PROBIO project, carried out by the Authors, were used. The sustainability of biodiesel produced from sunflower grown in central Italy is variable and depends on the nitrogen input and seasonal climatic conditions that affect the yields. The greenhouse gases savings
\end{abstract}

Correspondence: Daniele Duca, D3A - Dipartimento di Scienze Agrarie, Alimentari e Ambientali, Università Politecnica delle Marche, via Brecce Bianche, 60131 Ancona (AN), Italy.

Tel. +39.071.2204297 - Fax. +39.071.2204167. E-mail: d.duca@univpm.it

Contributions: DD and GR, conception and design; DD and EFP, analysis and interpretation of data; DD and GT, manuscript drafting and reviewing, references search.

Conflict of interests: the authors declare no conflict of interests.

Key words: sunflower, bioenergy chain, sustainability, biodiesel, greenhouse gases (GHG), GHG saving.

Acknowledgements: the authors would like to thank PhD Ilaria Beldomenico for helping in reviewing agricultural data.

Received for publication: 6 December 2013.

Accepted for publication: 28 January 2014.

CCopyright D. Duca et al., 2013

Licensee PAGEPress, Italy

Journal of Agricultural Engineering 2013; XLIV:222

doi:10.4081/jae.2013.222

This article is distributed under the terms of the Creative Commons Attribution Noncommercial License (by-nc 3.0) which permits any noncommercial use, distribution, and reproduction in any medium, provided the original author(s) and source are credited. of the Italian chain is $40 \%$ in average, greater than the required $35 \%$ and would be possible to assign this value as standard to the biofuel chain biodiesel from sunflower cultivated in central Italy. Using an averaged regional standard value guards against the possibility of considering unsustainable harvesting in unfavourable years and seeing it overestimated in the favourable ones.

\section{Introduction}

The search for renewable energies, alternative to fossil fuels, has value from an environmental point of view (IPCC, 2007) and also for other aspects, more directly related to the security of national economies (Asif and Muneer, 2007). The European Renewable Sources Directive (European Parliament and Council, 2009), Directive 2009/28/EC also known as RED, identifies for the Member States the targets to satisfy in terms of final energy consumption with energy coming from renewable sources and in terms of renewable energy content of the fuels used for transport. The effectiveness of the biofuels use in reducing the greenhouse effect, however, is very variable and the use of biofuels on a large scale can also cause negative effects at environmental, social and economic level. These aspects are often connected to each other and together define the overall sustainability of bioenergy, a topic widely debated by scientific organizations, industry, nongovernmental organizations, national governments and supranational institutions, engaged in identifying methods to evaluate and certify them (Van Dam et al., 2010). In particular, many of the protocols used for certification purposes are focused on the sustainability of biofuels and include only some environmental aspects [i.e., greenhouse gases (GHG) emissions], without considering the economic and social sides and ignoring the indirect effects of land use change. The latter aspect is the subject of a great debate among authors and institutions over its real impact on GHG balance (Searchinger et al., 2008; ClientEarth et al., 2010).

At European level, the RED gives the basic criteria for the estimation of sustainability of biofuels for transport and bio liquids and these criteria have been extended by the COM(2010)11 (European Commission, 2011), hereafter COM, in form of recommendations on solid and gaseous biofuels used for electrical, thermal and cooling production. In addition, the RED states that biofuels must be certified under a mass balance system and some voluntary certification schemes compliant to the Directive have already been approved by the EC (European Commission, 2012). A sustainability criterion is to obtain a certain minimum reduction of the GHG emissions when the alternative chain is compared with those based on fossil fuels. This threshold is defined to be $35 \%$ at the entry into force of RED (December 2010) and will increase to 50\% from $1^{\text {st }}$ January 2017 and to $60 \%$ from $1^{\text {st }}$ January 2018 for plants starting production after December $31^{\text {th }}, 2016$. For energy chains using waste and residues as raw materials, GHG savings thresholds are fulfilled by law. In RED 
Directive the methodologies of calculation of the GHG emissions are indicated; there are also some GHG saving standard values referring to the main chains that can be used avoiding calculations. The European Committee for Standardization (CEN), through its Technical Committee 383 , is working on these issues and has already produced draft technical standards, as reported in the website of the EC Transparency Platform (CEN/TC 383, 2012), which aim to facilitate the RED application.

These methodologies, however, can lead with different interpretations originating different final results and causing problems. To overcome this, the European Commission launched the project BIOGRACE (BIOGRACE Project, 2012) on the harmonization of methods for calculating the GHG emission savings. The aim was to provide a list of conversion factors and a harmonized set of spreadsheets that can be used by Member States in their national legislation.

The RED gives to the States also the possibility to identify standard regional values for the cultivation steps that could be utilized for the certification of the biofuels. This paper aims to give a contribution to the definition of these values considering the RED methodology implemented by the BIOGRACE to the sunflower cropped in the area of central Italy which is characterized by a hilly landscape and notirrigated crops.

\section{Materials and methods}

\section{General aspects}

This work has paid particular attention to the sunflower yields and to the nitrogen fertilization assessments, based on regional data. In fact, these are the factors most affecting the GHG balance. For the other chain steps, process and transport, not strongly linked to the area, the RED values were used.

To determine the average input and output of sunflower cultivation in the central Italy, the PROBIO project results carried out by the Authors in the Marche region (Riva et al., 2006) have been used. In this region, located in central eastern Italy and highly representative of the area, in 2011 has been produced the $33 \%$ of the total Italian sunflower production. This figure raises to $70 \%$ if we consider all the central Italy (Marche, Umbria, Tuscany).

In the PROBIO project different cropping techniques (Table 1) were observed and studied on the field. The inputs used in the different cropping techniques are reported in Table 2 . The results refer to the years 2003-2005 and have been carried out in different locations, farm size and agronomic inputs. Table 3 shows the relevant range of

Table 1. Cultivation techniques considered in PROBIO project (Carried out operations are identified by an "X").

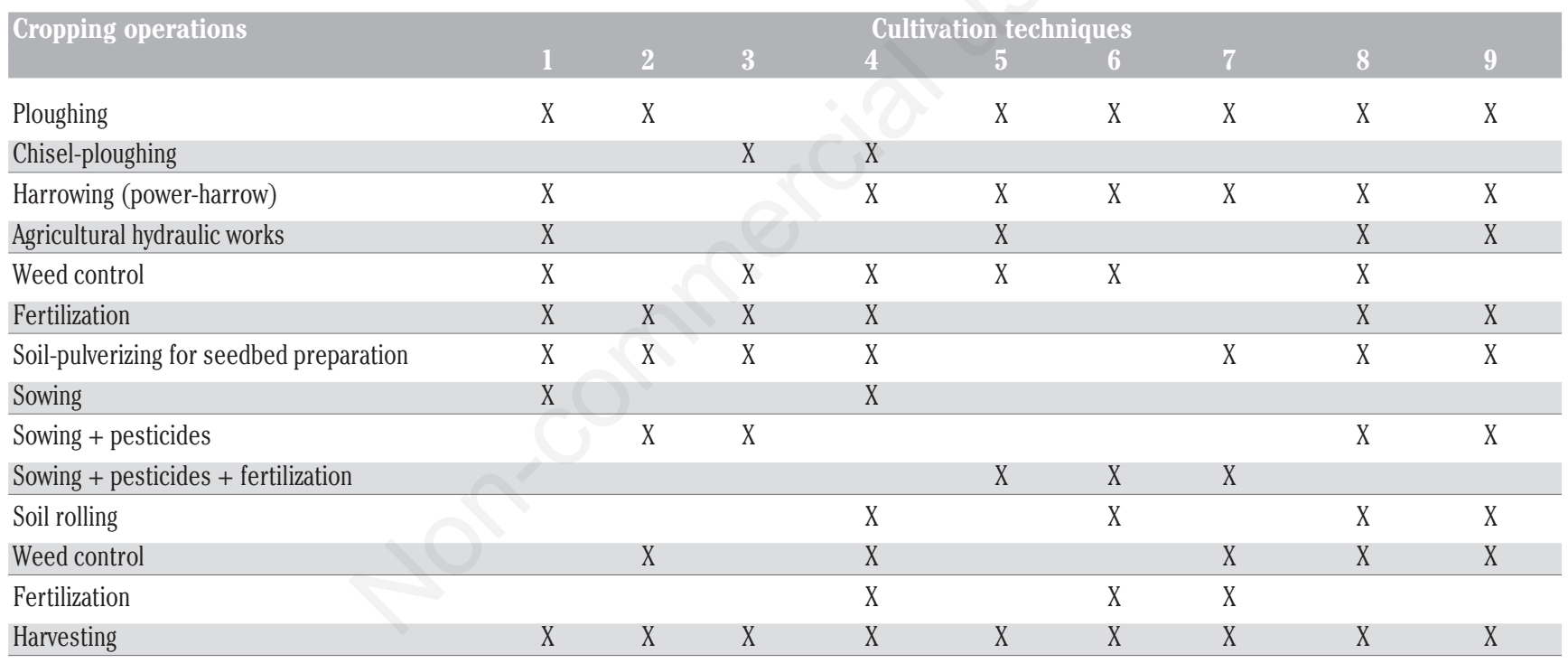

Table 2. Input used in the different cropping techniques.

\begin{tabular}{|c|c|c|c|c|c|c|}
\hline Cultivation technique & $\begin{array}{c}\text { Diesel } \\
\left(\mathrm{MJ} \mathrm{ha}^{-1}\right)\end{array}$ & $\begin{array}{l}\text { N-fertilizer } \\
\left(\mathrm{kg} \mathrm{N} \mathrm{ha}^{-1}\right)\end{array}$ & $\begin{array}{l}\mathrm{P}_{2} \mathrm{O}_{5} \text {-fertilizer } \\
\left(\mathrm{kg} \mathrm{P}_{2} \mathrm{O}_{5} \mathrm{ha}^{-1}\right)\end{array}$ & $\begin{array}{l}\mathrm{K}_{2} \mathrm{O} \text {-fertilizer } \\
\left(\mathrm{kg} \mathrm{K}_{2} \mathrm{O} \mathrm{ha}^{-1}\right)\end{array}$ & $\begin{array}{l}\text { Pesticides } \\
\left(\mathrm{kg}^{2} \text { a.i. } \mathrm{ha}^{-1}\right)\end{array}$ & $\begin{array}{l}\text { Seeding material } \\
\qquad\left(\mathrm{kg} \mathrm{ha}^{-1}\right)\end{array}$ \\
\hline 1 & 3802 & 96 & 69 & - & 0.7 & 5.5 \\
\hline 2 & 4139 & 99 & 71 & - & 2.2 & 5.5 \\
\hline 3 & 2113 & 99 & 71 & - & 2.2 & 5.5 \\
\hline 4 & 2909 & 42 & 12 & 12 & 0.9 & 5.5 \\
\hline 5 & 3805 & - & 74 & - & 3.4 & 6.0 \\
\hline 6 & 4150 & 101 & 34 & - & 1.2 & 6.5 \\
\hline 7 & 4222 & 87 & 49 & - & 1.1 & 5.0 \\
\hline 8 & 4900 & 131 & 115 & - & 2.4 & 9.0 \\
\hline 9 & 4730 & 102 & 92 & - & 1.6 & 5.5 \\
\hline
\end{tabular}

a.i., active ingredient. 
inputs and the average data used here for calculations.

In general, the nitrogen fertilization rate is in line with that of other studies that make reference to central Italy (Chiaramonti and Recchia, 2010). The cultivation of the sunflower is done almost always without irrigation. As a consequence, even if the fertilization is the same in the different years, the yield varies depending on the intensity of the rainfalls during the critical crop phenologic stages that influence the use of nutrients by the plant. Given the importance of the thermo-pluviometric trend on crop yields without irrigation, the trends in the period 2003-2005 (ASSAM, 2012) and the historical averages (1958-1979) related to the Marche region are shown in Tables 4 and 5 .

Meteorological trends show three very different climatic years. From December 2002 to November 2003 rainfall decreased of more than 13\% with respect to the historical average while temperature increased of $4.3^{\circ} \mathrm{C}$. In particular, considering the period of cultivation of the sunflower (April-September), the rainfall decrease ( $-56 \%$ in spring and $-43 \%$ in summer) and the temperature increase $\left(+4.9^{\circ} \mathrm{C}\right.$ in June and $+4.7^{\circ} \mathrm{C}$ in August) caused serious water deficit conditions with direct consequences on sunflower grown without irrigation. In the following year although remains a relatively rainfall scarcity condition $(+5 \%$ spring and $-37 \%$ in summer), the temperatures were closer to the historical average and these conditions result in a more favourable water balance for sunflower cultivation. Finally in 2005, characterized by high rainfall and low temperatures, the water balance was very favourable to sunflower crop.

Taking into account the reference input established in Table 3 and considering the yields reported in PROBIO project for the years 20032005 , in Table 6 are summarized the main input and output of the cultivation step compared with those of the related RED chain. The yield related to Marche in average climatic year is in line with the National Institute of Statistics data (ISTAT, 2012).

With this setting and subsequent calculations it is possible to highlight the influence of climate trends on the cultivation sustainability.

\section{Calculation of greenhouse gases emission savings}

The life-cycle analysis (LCA) is considered the most appropriate method to assess the GHG savings. To perform the LCA, the RED contains some general rules and defines the issues to be considered or not in the estimation, as reported in the following equation:

$$
E=e_{e c}+e_{l}+e_{p}+e_{t d}+e_{u}-e_{s c a}-e_{c c s}-e_{c c r}-e_{e e},
$$

where:

$\mathrm{E}=$ total emission from the use of the fuel;

$\mathrm{e}_{\mathrm{ec}}=$ emissions from the extraction or cultivation of raw materials;

$\mathrm{e}_{\mathrm{l}}=$ annualised emissions from carbon stock changes caused by land-

Table 3. Range of cultivation inputs derived from PROBIO project and average data utilized in this work.

\begin{tabular}{|c|c|c|c|c|c|c|}
\hline & $\begin{array}{c}\text { Diesel } \\
\left(\mathrm{MJ} \mathrm{ha}^{-1}\right)\end{array}$ & $\begin{array}{l}\mathrm{N} \text {-fertilizer } \\
\left(\mathrm{kg} \mathrm{Nha}^{-1}\right)\end{array}$ & $\begin{array}{l}\mathrm{P}_{2} \mathrm{O}_{5} \text {-fertilizer } \\
\left(\mathrm{kg} \mathrm{P}_{2} \mathrm{O}_{5} \mathrm{ha}^{-1}\right)\end{array}$ & $\begin{array}{l}\mathrm{K}_{2} \mathrm{O} \text {-fertilizer } \\
\left(\mathrm{kg} \mathrm{K}_{2} \mathrm{O} \mathrm{ha} \mathrm{ha}^{-1}\right)\end{array}$ & $\begin{array}{l}\text { Pesticides } \\
\left(\mathrm{kg} \text { a.i. } \mathrm{ha}^{-1}\right)\end{array}$ & $\begin{array}{l}\text { Seeding material } \\
\left(\mathrm{kg} \mathrm{ha}^{-1}\right)\end{array}$ \\
\hline Standard deviation & 873 & 25 & 30 & 4 & 0,9 & 1 \\
\hline Range & $2112-4900$ & $42-131$ & $13-115$ & $0-12$ & $0.7-3.4$ & $5-9$ \\
\hline Data used for estimations & 3633 & 80 & 50 & 0 & 2.0 & 6 \\
\hline
\end{tabular}

a.i., active ingredient.

Table 4. Pluviometric trend in the period 2003-2005 related to the Marche region ( $\mathrm{mm})$.

\begin{tabular}{lccccccccccccc} 
& Dec* & Jan & Feb & Mar & Apr & May & Jun & Jul & Aug & Sep & Oct & Nov \\
2003 & 227.8 & 64.4 & 29.0 & 29.4 & 42.6 & 21.1 & 49.3 & 29.9 & 33.0 & 60.3 & 135.7 & 43.3 \\
2004 & 43.8 & 56.5 & 62.8 & 46.6 & 102.7 & 72.8 & 65.5 & 22.6 & 36.4 & 112.3 & 90.1 & 105.0 \\
\hline 2005 & 114.8 & 95.5 & 44.3 & 33.4 & 100.9 & 48.8 & 51.5 & 54.7 & 118.9 & 80.6 & 124.7 & 157.3 \\
Historical average (1958-1979) & 87.1 & 66.3 & 65.4 & 75.3 & 77.0 & 59.1 & 66.0 & 54.1 & 76.8 & 81.2 & 82.4 & 95.5 \\
\hline
\end{tabular}

*Previous year.

Table 5. Thermometric trend in the period 2003-2005 related to the Marche region $\left({ }^{\circ} \mathrm{C}\right)$.

\begin{tabular}{lccccccccccccc} 
& Dec* & Jan & Feb & Mar & Apr & May & Jun & Jul & Aug & Sep & Oct & Nov \\
2003 & 7.2 & 5.2 & 2.3 & 8.6 & 11.3 & 18.7 & 24.9 & 25.7 & 27.0 & 18.1 & 13.7 & 10.2 \\
2004 & 5.8 & 4.3 & 6.0 & 7.2 & 11.3 & 14.5 & 20.6 & 23.7 & 23.7 & 18.9 & 16.5 & 9.5 \\
\hline 2005 & 6.5 & 3.6 & 2.5 & 8.0 & 11.5 & 17.7 & 21.4 & 23.8 & 20.8 & 18.4 & 13.3 & 8.7 \\
Historical average (1958-1979) & 5.8 & 4.7 & 6.3 & 8.4 & 11.8 & 16.3 & 20.0 & 22.5 & 22.3 & 18.8 & 14.3 & 9.9 \\
\hline$*$
\end{tabular}

*Previous year.

Table 6. Cultivation steps considered in the work.

\begin{tabular}{|c|c|c|c|c|c|c|c|}
\hline $\begin{array}{l}\text { Sunflower } \\
\text { cropping }\end{array}$ & $\begin{array}{c}\text { Diesel } \\
\left(\mathrm{MJ} \mathrm{ha}^{-1}\right)\end{array}$ & $\begin{array}{l}\text { N-fertilizer } \\
\left(\mathrm{kg} \mathrm{N} \mathbf{h a}^{-1}\right)\end{array}$ & $\begin{array}{l}\mathrm{P}_{2} \mathrm{O}_{5} \text {-fertilizer } \\
\left(\mathrm{kg} \mathrm{P}_{2} \mathrm{O}_{5} \mathrm{ha}^{-1}\right)\end{array}$ & $\begin{array}{l}\mathrm{K}_{2} \mathrm{O} \text {-fertilizer } \\
\left(\mathrm{kg} \mathrm{K}_{2} \mathrm{O} \mathrm{ha}^{-1}\right)\end{array}$ & $\begin{array}{l}\text { Pesticides } \\
\left(\mathrm{kg} \text { a.i. } \mathrm{ha}^{-1}\right)\end{array}$ & $\begin{array}{l}\text { Seeding material } \\
\qquad\left(\mathrm{kg} \mathrm{ha}^{-1}\right)\end{array}$ & $\begin{array}{c}\text { Yield } \\
\left(\operatorname{tdm}_{\left.h a^{-1}\right)}\right.\end{array}$ \\
\hline RED (JEC, 2008) & 68.7 & 39 & 30 & 22 & 2 & 6 & 2.2 \\
\hline Marche (average climatic year) & 84.5 & 80 & 50 & 0 & 2 & 6 & 2.2 \\
\hline Marche (unfavourable climatic year) & 84.5 & 80 & 50 & 0 & 2 & 6 & 1.6 \\
\hline Marche (favourable climatic year) & 84.5 & 80 & 50 & 0 & 2 & 6 & 3.2 \\
\hline
\end{tabular}


use change;

$\mathrm{e}_{\mathrm{p}}=$ emissions from processing;

$\mathrm{e}_{\mathrm{td}}=$ emissions from transport and distribution;

$\mathrm{e}_{\mathrm{u}}=$ emissions from the fuel in use;

$\mathrm{e}_{\text {sca }}=$ emission saving from soil carbon accumulation via improved agricultural management;

$\mathrm{e}_{c c s}=$ emission saving from carbon capture and geological storage;

$\mathrm{e}_{\mathrm{ccr}}=$ emission saving from carbon capture and replacement;

$\mathrm{e}_{\mathrm{ee}}=$ emission saving from excess electricity from cogeneration.

The methodology considers the allocation of emissions between products and co-products, according to their energy content. The indirect emissions due to the manufacturing of the machinery and the equipment aren't taken into account. The same for those associated with the use of biofuels and bio liquids.

GHG emissions of the entire chain, expressed in $\mathrm{gCO}_{2}$ equivalent, correspond to the sum of the emissions coming from each individual step related to $1 \mathrm{MJ}$ of final fuel produced. The result must be increased with the emissions coming from a possible land use change (European Commission, 2010) and it can also be reduced by any saving achieved through the increased carbon in the soil or by other practices able to sequester carbon dioxide.

In this work, land use changes effects were not considered because in this case the energy crop don't cause land use change and don't subtract raw material to the food or industrial market.

All the input data have been referred to the energy unit of produced biomass (MJ) using the standard lower calorific values contained in BIOGRACE and then have been multiplied by the relative emission factors reported in Table 7. In this way, the emissions of the cultivation step in terms of $\mathrm{gCO}_{2 \mathrm{eq}} \mathrm{MJ}_{\text {biomass }}{ }^{-1}$ were obtained. To express emissions in $\mathrm{gCO}_{2 \mathrm{eq}} \mathrm{MJ}_{\text {biofuel }}{ }^{-1}$ were used the same conversion factors used for the related RED chain, reported in the spread sheet provided by BIOGRACE for the sunflower. The calculation of $\mathrm{N}_{2} \mathrm{O}$ emissions from the soil was made using the IPCC Tier 1 approach, in line with the RED recommendations. The results obtained are thus directly comparable with the related RED chain.

For process and transport steps, the standard values indicated in RED Annex V were used. Finally, to calculate the emission savings for the biodiesel produced from sunflower, the relationship defined in RED was used considering that for biodiesel employed for automotive use EF is $83.8 \mathrm{gCO}_{2 \mathrm{eq}} \mathrm{MJ}^{-1}$. GHG savings related to the case of production of only electricity, only thermal or cogeneration are, respectively, 91,77 and $85 \mathrm{gCO}_{2 \mathrm{eq}} \mathrm{MJ}^{-1}$.

$$
\text { GHG SAVING }=(\mathrm{EF}-\mathrm{EB}) / \mathrm{EF}
$$

where:

$\mathrm{EB}$ = total emissions from the biofuel or bio liquid;

$\mathrm{EF}=$ total emission from the fossil fuel comparator.

\section{Results}

In Table 8 are reported the results of the calculations performed to evaluate the emissions of the single cultivation step. Data are expressed in $\mathrm{gCO}_{2 \mathrm{eq}} \mathrm{kg}_{\text {sunflowerseed }}{ }^{-1}$ : they are not directly related to the biofuel, but are useful to analyse the inputs that have the greatest effect on overall emissions of this step.

Table 7. Emission factors used taken from BIOGRACE.

\begin{tabular}{lcccc} 
Cultivation input & $\mathrm{gCO}_{2} \mathrm{~kg}^{-1}$ & $\mathrm{gCH}_{4} \mathrm{~kg}^{-1}$ & $\mathrm{gN}_{2} \mathrm{O} \mathrm{kg}$ & $\mathrm{gCO}_{2 \text { eq }} \mathrm{kg}^{-1}$ \\
N-fertiliser $(\mathrm{kg} \mathrm{N})$ & 2827.0 & 8.68 & 9.6418 & 5880.6 \\
$\mathrm{P}_{2} \mathrm{O}_{5}$-fertiliser $\left(\mathrm{kg} \mathrm{P}_{2} \mathrm{O}_{5}\right)$ & 964.9 & 1.33 & 0.0515 & 1010.7 \\
\hline $\mathrm{K}_{2} \mathrm{O}$-fertiliser $\left(\mathrm{kg} \mathrm{K}_{2} \mathrm{O}\right)$ & 536.3 & 1.57 & 0.0123 & 576.1 \\
CaO-fertiliser $(\mathrm{kg} \mathrm{CaO})$ & 119.1 & 0.22 & 0.0183 & 129.5 \\
\hline Pesticides & 9886.5 & 25.53 & 1.6814 & $10,971.3$ \\
Seeds-sunflower & 412.1 & 0.91 & 1.0028 & 729.9 \\
\hline Energy input & $\mathrm{gCO}_{2} \mathrm{MJ}^{-1}$ & $\mathrm{gCH}_{4} \mathrm{MJ}^{-1}$ & $\mathrm{gN}_{2} \mathrm{O} \mathrm{MJ}-1$ & $\mathrm{gCO}_{2 e q} \mathrm{MJ}^{-1}$ \\
Diesel & 87.6 & 0.00 & 0.0000 & 87.6 \\
\hline Electricity & 119.4 & 0.29 & 0.0054 & 127.7 \\
\hline
\end{tabular}

Table 8. Emissions of the cultivation steps considered (in $\mathrm{gCO}_{2 \mathrm{eq}} \mathrm{kg}_{\text {sunflowerseed }}{ }^{-1}$ ).

\begin{tabular}{lcccc} 
Factors & RED & $\begin{array}{c}\text { Marche average } \\
\text { climatic year }\end{array}$ & $\begin{array}{c}\text { Marche unfavourable } \\
\text { climatic year }\end{array}$ & $\begin{array}{c}\text { Marche favourable } \\
\text { climatic year }\end{array}$ \\
Diesel & $106(26 \%)$ & $133(21 \%)$ & $177(21 \%)$ & $91(20 \%)$ \\
$\mathrm{N}$ fertilizer & $94(23 \%)$ & $196(31 \%)$ & $261(31 \%)$ & $134(30 \%)$ \\
\hline $\mathrm{K}_{2} \mathrm{O}$ fertilizer & $5(1 \%)$ & $0(0 \%)$ & $0(0 \%)$ & $0(0 \%)$ \\
$\mathrm{P}_{2} \mathrm{O}_{5}$ fertilizer & $12(3 \%)$ & $21(3 \%)$ & $28(3 \%)$ & $14(3 \%)$ \\
\hline Pesticides & $9(2 \%)$ & $9(1 \%)$ & $12(1 \%)$ & $6(1 \%)$ \\
Seeding material & $2(0 \%)$ & $2(0 \%)$ & $3(0 \%)$ & $1(0 \%)$ \\
\hline Field $\mathrm{N}_{2} \mathrm{O}$ emissions & $174(43 \%)$ & $277(43 \%)$ & $832(100 \%)$ & $207(46 \%)$ \\
Total & $403(100 \%)$ & $638(100 \%)$ & $454(100 \%)$ & \\
\hline
\end{tabular}


In Table 9 the emissions related to the considered biofuel chains are reported. Process and transport emissions are the RED standard ones. Emissions from the cultivation step were calculated considering a drying process identical to that considered in the related RED chain; the energy allocation of the emissions between products and co-products was defined by the conversion efficiencies used in the BIOGRACE spread sheet: the differences in the total emissions are therefore attributable only to the cultivation step. In Table 10 are reported the GHG savings obtainable with the considered biofuel chains in case of transport, heat and electricity production, cogeneration.

\section{Discussion}

The Italian sunflower chain in comparison with the RED minimum required level of $35 \%$ is sustainable only in average and favourable climatic years. The emissions of the cultivation step are, in any case, higher than the disaggregated standard values reported for the related RED chain. This is mainly due to the low nitrogen fertilization considered for the RED chain that does not represent the reality in central Italy.

The present analysis and the scientific literature reveal a close connection of the emissions during cultivation to the nitrogen fertilization. If the nitrogen input is low, however, it is possible to achieve significant reduction in GHG emissions, but seldom farmers use low inputs. It is important to underline that farmers normally adopt the maximum fertilization rate permitted by law. Nevertheless, the GHG savings of the Italian chain is $40 \%$ in average, greater than the required $35 \%$ and would be possible to assign this value as standard to the biofuel chain biodiesel from sunflower cultivated in central Italy.

It must be stressed that, with the increase of the minimum threshold to $50 \%$ provided by RED in 2016 , the Italian chain can't be considered sustainable, as well as other Italian energy crops, unless making sub- stantial enhancements of the cultivation step.

The important aspect that arises from this work is the dependence of the sustainability of sunflower cultivation without irrigation from the climatic conditions. In general, with irrigated crops it is possible to optimize the inputs, according to the expected yields. In addition, the additional GHG emissions by irrigation are easily balanced by the maximization of the crop productivity.

\section{Conclusions}

The sustainability of liquid biofuels produced from sunflower grown without irrigation is variable and depends on the nitrogen input and seasonal climatic conditions that affect the yields. In real cultivation conditions for central Italy, the nitrogen input is normally higher than the one considered in RED chain. This is mainly due to the aim of farmers to maximize the production. To make this production sustainable, the nitrogen input has to be balanced with the yield. In unfavourable years the crop can't use all the nitrogen input because limited by other factors like water. In these cases the only way to obtain a sustainable production is to limit the nitrogen input, but this is practically impossible because the yield is not predictable a priori. Using an averaged regional standard value guards against the possibility of considering unsustainable harvesting in unfavourable years and seeing it overestimated in the favourable ones. This fact is important for crops such as sunflower, normally cultivated without irrigation in Central Italy. A possible improvement of sustainability can be achieved for example by using organic-N from residues coming from zootechnics and anaerobic digestion plants in substitution of mineral-N for fertilizing operations. This could reduce the GHG emissions of the cultivation step by about $20-30 \%$. Apart these considerations, however, it seems evident that the sustainability could be assured only controlling inputs and outputs of cultivations that mean, basically, to perform and optimize the irrigation.

Table 9. Emissions of the considered chains.

\begin{tabular}{|c|c|c|c|c|}
\hline Biofuel chain & Cultivation* & $\begin{array}{l}\text { emissior } \\
\text { Process }\end{array}$ & $\begin{array}{l}\text { Jiodiesel }^{-1} \text { ) } \\
\text { Transport }\end{array}$ & Total \\
\hline Biodiesel from sunflower RED & 18 & 22 & 1 & 41 \\
\hline Biodiesel from sunflower Marche - average climatic year & 28 & 22 & 1 & 51 \\
\hline Biodiesel from sunflower Marche - unfavourable climatic year & 36 & 22 & 1 & 59 \\
\hline Biodiesel from sunflower Marche - favorable climatic year & 20 & 22 & 1 & 43 \\
\hline
\end{tabular}

GHG, greenhouse gases. *Drying included.

Table 10. Greenhouse gases savings obtainable with the considered biofuel chains.

\begin{tabular}{lcccc} 
Biofuel chain & \multicolumn{3}{c}{ Energetic use } \\
Biodiesel from sunflower RED & Transport & Electricity & Heat & Cogeneration \\
Biodiesel from sunflower Marche - average climatic year & $51 \%$ & $55 \%$ & $47 \%$ & $52 \%$ \\
\hline Biodiesel from sunflower Marche - unfavourable climatic year & $40 \%$ & $44 \%$ & $34 \%$ & $40 \%$ \\
Biodiesel from sunflower Marche - favourable climatic year & $30 \%$ & $35 \%$ & $23 \%$ & $31 \%$ \\
\hline
\end{tabular}




\section{References}

Asif M., Muneer T. 2007. Energy supply, its demand and security issues for developed and emerging economies. Renew. Sust. Energ. Rev. 11:1388-413.

ASSAM - Agenzia per i Servizi nel Settore Agroalimentare delle Marche. 2012. Available from: http://www.meteo.marche.it/ Accessed: May 2012.

BIOGRACE Project. 2012. Harmonised calculations of biofuel greenhouse gas emissions in Europe. Available from: http://www. biograce.net Accessed: May 2012.

CEN/TC 383. 2012. Sustainably produced biomass for energy applications. Available from: http://www.cen.eu/cen/Sectors/Sectors/ UtilitiesAndEnergy/Fuels/Pages/Sustainability.aspx Accessed: May 2012.

Chiaramonti D., Recchia L. 2010. Is life cycle assessment (LCA) a suitable method for quantitative CO2 saving estimations? the impact of field input on the LCA results for a pure vegetable oil chain. Biomass. Bioenerg. 34:787-97.

ClientEarth, Transport \& Environment, European Environmental Bureau, BirdLife International. 2010. Application for Annulment under Article 263 of the Treaty on the Functioning of the European Union. Available from: http://www.clientearth.org/reports/biofuelcase-clientearth-and-others-v-european-commission-application. pdf Accessed: December 2013.

European Commission. 2010. Commission decision on guidelines for the calculation of land carbon stocks for the purpose of Annex $V$ to Directive 2009/28/EC, 2010/335/EU. In: Official Journal, L 151, 17/06/2010, pp 19-41.

European Commission. 2011. Report from the Commission to the
Council and the European Parliament on sustainability requirements for the use of solid and gaseous biomass sources in electricity, heating and cooling SEC(2010) 65 final SEC(2010) 66 final /* COM/2010/0011 final */ Available from: http://eur-lex.europa.eu/ LexUriServ/LexUriServ.do?uri=CELEX:52010DC0011:EN:HTML:NOT

European Commission. 2012. Recognised voluntary schemes. Available from: http://ec.europa.eu/energy/renewables/biofuels/sustainability_schemes_en.htm Accessed: December 2012.

European Parliament, European Council. 2009. Directive 2009/28/EC on the promotion of the use of energy from renewable sources and amending and subsequently repealing Directives 2001/77/EC and 2003/30/EC. In: Official Journal, L 140, 05/06/2009, pp 0016-62.

IPCC. 2007. Fourth Assessment Report (AR4), Working Group I. UNEP, Cambridge University Press, New York, NY, USA.

ISTAT. 2012. Agricoltura e zootecnia. Available from: http://agri.istat.it/ Accessed: May 2012.

JEC Joint Research Centre-EUCAR-CONCAWE. 2008. Well-to-wheels analysis of future automotive fuels and powertrains in the european context. Available from: http://re.jrc.ec.europa.eu/biof/html/ input_data_ghg.htm Accessed: May 2012.

Riva G., Foppa Pedretti E., Toscano G., Cerioni R., Scrosta V., Ciaschini F., Duca D., Bordoni A., 2006. Agroenergie: filiere locali per la produzione di energia elettrica da girasole. Ed. ASSAM, Ancona, Italy.

Searchinger T., Heimlich R., Houghton R.A., Dong F., Elobeid A., Fabiosa J., Tokgoz S, Hayes D, Yu TH. 2008. Use of U.S. croplands for biofuels increases greenhouse gases through emissions from land-use change. Science. 319:1238-40.

Van Dam J., Junginger M., Faaij A.P.C. 2010. From the global efforts on certification of bioenergy towards an integrated approach based on sustainable land use planning. Renew. Sust. Energ. Rev. 14:2445-72. 